\title{
Biotreatment of Effluent from Cassava Processing Using Powdered Seeds of Moringa oleifera
}

\author{
Abiye A. Ibiene, Nelly C. Ekwuribe, Anwuli U. Osadebe ", Phillip O. Okerentugba \\ Department of Microbiology, University of Port Harcourt, P.M.B. 5323, Choba, Nigeria
}

Received March 27, 2021; Revised May 5, 2021; Accepted May 28, 2021

\section{Cite This Paper in the following Citation Styles}

(a): [1] Abiye A. Ibiene, Nelly C. Ekwuribe, Anwuli U. Osadebe, Phillip O. Okerentugba , "Biotreatment of Effluent from Cassava Processing Using Powdered Seeds of Moringa oleifera," Bioengineering and Bioscience, Vol. 8, No. 2, pp. 13 - 23, 2021. DOI: 10.13189/bb.2021.080201.

(b): Abiye A. Ibiene, Nelly C. Ekwuribe, Anwuli U. Osadebe, Phillip O. Okerentugba (2021). Biotreatment of Effluent from Cassava Processing Using Powdered Seeds of Moringa oleifera. Bioengineering and Bioscience, 8(2), 13 - 23. DOI: $10.13189 / b b .2021 .080201$.

Copyright $\odot 2021$ by authors, all rights reserved. Authors agree that this article remains permanently open access under the terms of the Creative Commons Attribution License 4.0 International License

\begin{abstract}
The world is facing increasingly more severe water security issues. It has, therefore, become imperative to develop sustainable, eco-friendly water management and recycling techniques. This study assessed the capacity of powdered seeds of Moringa oleifera to improve water quality of effluent from two (2) cassava processing plants in Umudike, Nigeria by measuring the variations in specific physicochemical and microbiological parameters of the samples. The biodegradability indices of the wastewater samples were determined as 0.513 and 0.507 for Plants 1 and 2 respectively indicating samples that were fairly biodegradable and treatable biologically. At the end of the 7-day study, turbidity reduced by $59.6 \%-63.2 \%$ while chemical oxygen demand (COD), biochemical oxygen demand (BOD) and total organic carbon values dropped by $66.6 \%-74.1 \%, 86.7 \%-88.2 \%$ and $67.0 \%-$ $72.6 \%$ respectively. Correlation analysis showed a strong positive correlation between $\mathrm{BOD}_{5}$ and COD for both Plants 1 and 2. The total heterotrophic and coliform bacteria were completely removed by around day 5 of the study. The observed bacterial isolates in the effluent at onset were Escherichia coli, Bacillus sp., Klebsiella sp., Salmonella sp., Streptococcus faecalis, Shigella sp. and Aerobacter aerogenes. This study confirms the efficiency of powdered seeds of $M$. oleifera in biotreatment of wastewater from cassava processing plants.
\end{abstract}

Keywords Biotreatment, Cassava, Coagulation, Effluent, Moringa oleifera, Wastewater, Water Quality

\section{Introduction}

Water is an essential element for life with access to quality water considered a fundamental human right. Water of good quality is central to ecosystem function and human physiology. The continued existence of life on earth depends on its sustained availability. Unfortunately, the world is facing increasingly more severe water security issues [1]. Competition for scarce water resources is a major concern such that it is an integral part of the United Nations Sustainable Development Goals (SDGs). It has been reported that the entire volume of usable water on the planet is only about $200,000 \mathrm{~km}^{3}$ hence the emphasis on water security, quality and management. Across the globe, there is a rapid depletion of ground and surface water resources. Anthropogenic activity, whether municipal, domestic or industrial, will normally require large quantities of water with wastewater as a consequence [2]. The quantity of wastewater generated across Europe and North America is estimated at $67 \mathrm{bn} \mathrm{m}^{3}$ annually [3]. In India, an estimated 13.5 billion litres of wastewater is generated daily with over $50 \%$ of said volume emptied untreated into the environment [4]. The recycling of wastewater plays a pivotal role in the global water security crisis. It has become imperative to develop safe, sustainable, cost effective and environmentally benign water purification and management approaches.

In most developing countries, wastewater is usually disposed of by discharging it untreated into surrounding waterways directly or indirectly by emptying into gutters 
where they still end up in aquatic ecosystems [5]. This drainage into water systems poses serious environmental problems with potential for disaster as it upsets the delicate balance in the ecosystem. Wastewater, in spite of its source, has several constituents that are known to be harmful to humans and animals [6,7]. These constituents may provide nutrients to indigenous aquatic organisms resulting in eutrophication amongst other environmental issues. Current non-biological methods of wastewater management often require complex designs consisting of multiple stages which make them relatively expensive and somewhat difficult to maintain [8]. The use of a coagulant in the treatment process has been identified as the most effective wastewater treatment technique. The coagulant facilitates sedimentation by increasing the specific gravity of particles via the formation of floc [9]. The employment of manufactured synthetic coagulants has several attendant demerits. Apart from the risk of groundwater contamination by certain chemical coagulants like aluminium sulphate and surface run-off of treated water loaded with inorganic residuals, the World Health Organisation, WHO [10] has highlighted the potential of several of these chemical coagulants to cause or exacerbate disease. The need for natural, environmentally friendly coagulants to support the treatment process has become apparent as natural coagulants are considered non-toxic and are biodegradable $[1,11,12]$.

Treatment of wastewater is aimed at improving water quality such that it can be safely discharged into aquatic systems or re-used. It is usually targeted at removal of suspended and dissolved organics by converting them into relatively inert end-products. It also targets a reduction in the microbial load of the water, thus, decreasing the pressure on the dissolved oxygen supply by lowering the biological oxygen demand. The constituent contaminants are reduced to a sludge that can then be disposed of safely. The sludge generated during the process will normally contain inorganic ions, metal ions, organic compounds and microorganisms [9]. Moringa oleifera (MO) is a tree of the Moringaceae family that is found in several countries across Asia, Africa and South America. It is the most studied of the 14 species of the genus. It has several common names including the drumstick tree, the horseradish tree or the benzolive tree $[1,13]$. Its properties have been studied extensively. Its role in wastewater treatment as a coagulant has been equated to that of commercial coagulants including those from calcium, aluminium and iron salts [14-20]. The observed sorbent and coagulant qualities of the seeds of M. oleifera have been linked to the soluble cationic proteins produced as by-products of the oil extraction process [21,22].

Cassava (Manihot esculenta) is an important food crop in most developing countries in Africa, Asia and South America. This root crop has gained increasing significance in sub-Saharan economic development and food security. Cassava is processed in diverse ways into various staple food products in Nigeria. Cassava processing mills, therefore, traverse the length and breadth of the country. Relatively large volumes of effluent are generated from the different processes required in cassava processing including washing, grating, moisture extraction, sieving and fermentation [23]; Padmaja [24] assert volumes of up to $3.68 \mathrm{~m}^{3}$ ton $^{-1}$ annually. Cassava processing plants have a high pollution potential due to both the quantity of wastewater produced and its constituents. Effluent from these plants are starch-laden and characterised by elevated levels of calcium, phosphorus and highly toxic cyanide $[21,25,26]$. The importance of this food crop informs studies into the different aspects of its processing including management of the wastewater produced. This study assessed the capacity of powdered seeds of $M$. oleifera to improve the water quality of effluent from two (2) cassava processing plants by measuring the variations in specific physicochemical and microbiological parameters of the wastewater.

\section{Materials and Methods}

\section{Sample Collection}

Effluent samples were collected from two cassava processing plants. One set of samples was collected from the Cassava Processing Unit of the National Root Crop Research Institute, Umudike, Nigeria while the second set of samples was collected from a randomly selected local cassava processing mill in the Umudike area in Ikwuano local government area of Abia state.

The composite sampling technique was used. A total of five composite samples were collected over time from each plant at the dewatering stage of the process. The samples were collected in clean sterile plastic bottles. Analysis was done within 3 hours of sample collection.

\section{Preparation of the Moringa oleifera (MO)-based Coagulant}

The MO seeds were obtained in pods from the Michael Okpara University of Agriculture, Umudike where they were also identified and authenticated. The seeds were sorted out manually and then ground using a laboratory blender. The powdered samples were sterilised, stored in labelled plastic bags and kept at room temperature in the dark until required.

The stock solution was obtained by mixing the powder with sterile distilled water to achieve a $2 \%$ suspension. The suspension was agitated using a magnetic stirrer at 100rpm for about $10-15$ minutes to extract the active agents in the powder. The milky solution was then filtered using Whatman's No. 1 filter paper. The filtrate was used for the water treatment set-ups.

\section{Water Treatment Experiment}

After addition of the MO-based filtrate to the 
wastewater, the mixture was stirred at $120 \mathrm{rpm}$ for 1 minute then at $40 \mathrm{rpm}$ for 20 minutes to facilitate the sedimentation process. The treated wastewater was covered and left to settle for about an hour before initial sampling [27,28]. The control experiments consisted of wastewater samples without MO-based coagulant applied.

The effect of the MO-based coagulant on the physicochemical, biological and microbiological properties of the wastewater was observed. Sampling was done at 24-hour intervals over a 7-day period. Samples were collected using a sterile pipette.

\section{Physicochemical Analysis of Water Samples}

\section{Determination of Turbidity}

Based on the method recommended by [29], the turbidity was determined using a turbidity meter (Jenway, UK) and standard solutions.

\section{Determination of $p H$}

The $\mathrm{pH}$ values of the water samples were determined by a combined glass calomel electrode and a $\mathrm{pH}$ meter (Jenway, UK).

\section{Determination of Total Organic Carbon (TOC) Content}

The colorimetric method was employed [30].

\section{Biological Analysis of Water Samples}

Determination of Chemical Oxygen Demand (COD) and Five Day Biological Oxygen Demand $\left(B O D_{5}\right)$

The $\mathrm{COD}$ and $\mathrm{BOD}_{5}$ of the samples were determined using the methods outlined by [28]. COD was determined by the dichromate closed reflux method. For $\mathrm{BOD}_{5}$, the sample was incubated at $20^{\circ} \mathrm{C}$ for 5 days and the oxygen consumed was measured.

Determination of Correlation between $\mathrm{COD}$ and $\mathrm{BOD}_{5}$ and the Biodegradability Index (BI)

The biodegradability index is a measure of the relationship between chemical oxygen demand and five-day biochemical oxygen demand for the water samples. It is described as the $\mathrm{BOD}_{5} / \mathrm{COD}$ ratio at different points. Plots of $\mathrm{BOD}_{5}$ values against $\mathrm{COD}$ values were obtained and used in regression analysis to develop the corresponding correlation coefficients [31].

\section{Enumeration of Total Heterotrophic Bacteria}

The media used for determination of microbial abundance were nutrient agar (NA) and Eosin Methylene blue (EMB) agar. All the media used were prepared according to the manufacturers' instructions and sterilised by autoclaving.

The total viable bacterial count (TVC) was determined using the pour plate technique on nutrient agar. Following serial dilution, $1 \mathrm{ml}$ aliquots of the water samples were plated unto the appropriate medium in triplicate with incubation at $35^{\circ} \mathrm{C}$ for 48 hours. Only plates with counts of $30-300$ colonies were considered.

\section{Determination of Total Coliform Count}

The multiple tube fermentation technique was employed in the enumeration of coliform bacteria in a known volume of treated wastewater sample [32]. The coliform bacteria were detected and quantitated by their ability to grow and produce gas in lactose-containing liquid medium at $37^{\circ} \mathrm{C}$ for 48 hours. Following incubation, the abundance of coliforms was determined by noting the number of positive and negative tubes and comparing this to a standardised MPN table. The confirmatory test for the presumptive positive tubes in the total coliform enumeration was carried out to verify the presence of coliform and to detect any false positive results. The presence of coliforms was confirmed via isolation on EMB medium.

\section{Characterisation of Bacterial Isolates}

Bacteriological analysis was performed using nutrient agar and Eosin-Methylene blue agar both prepared according to the manufacturers' instructions. The media were sterilised in an autoclave at $121^{\circ} \mathrm{C}$ and 15 psi for 30 minutes. The isolated bacteria were characterized based on the morphological, microscopic, and biochemical properties as proposed by Cheesbrough [33] and Holt et al. [34].

\section{Results}

The baseline characteristics of the wastewater samples are outlined in Table 1 while Figure 1 illustrates the observed variations in the physicochemical properties of the wastewater samples. At the end of the 7-day study, turbidity dropped from 99 NTU to 40 NTU and 95 NTU to 35 NTU for Plants 1 and 2 respectively. Total organic carbon reduced by about $67 \%$ in Plant 1 to $62.4 \mathrm{mg} / \mathrm{L}$ and by about $73 \%$ to $51.3 \mathrm{mg} / \mathrm{L}$ in Plant 2 . Similar results were observed with the mean values for $\mathrm{pH}$ (Figure 1).

Table 1. Baseline Characteristics of Wastewater

\begin{tabular}{ccc}
\hline & PLANT 1 & PLANT 2 \\
\hline Colour & Pale yellow & Pale yellow \\
Odour & Offensive & Offensive \\
Temperature $\left({ }^{\circ} \mathrm{C}\right)$ & $29.00 \pm 0.11$ & $29.20 \pm 0.17$ \\
Turbidity $(\mathrm{NTU})$ & $99.00 \pm 0.88$ & $95.00 \pm 0.54$ \\
pH & $3.10 \pm 0.07$ & $3.08 \pm 0.05$ \\
TOC $(\mathrm{mg} / \mathrm{L})$ & $188.28 \pm 1.28$ & $187.43 \pm 0.96$ \\
COD $(\mathrm{mg} / \mathrm{L})$ & $323.18 \pm 2.35$ & $322.30 \pm 3.04$ \\
BOD $(\mathrm{mg} / \mathrm{L})$ & $164.16 \pm 3.33$ & $163.63 \pm 3.02$ \\
TVC $($ LogCFU/100ml & $4.98 \pm 0.76$ & $4.93 \pm 0.65$ \\
TCC $($ LogCFU/100ml & $4.90 \pm 0.52$ & $4.91 \pm 0.23$ \\
\hline
\end{tabular}

Values are expressed as the mean \pm Standard Deviation

TCC - Total Coliform count; TVC - Total Viable Bacterial Count; TOC Total Organic Carbon; BOD $_{5}$ - Five-day Biochemical Oxygen Demand; COD - Chemical Oxygen Demand 
(A)

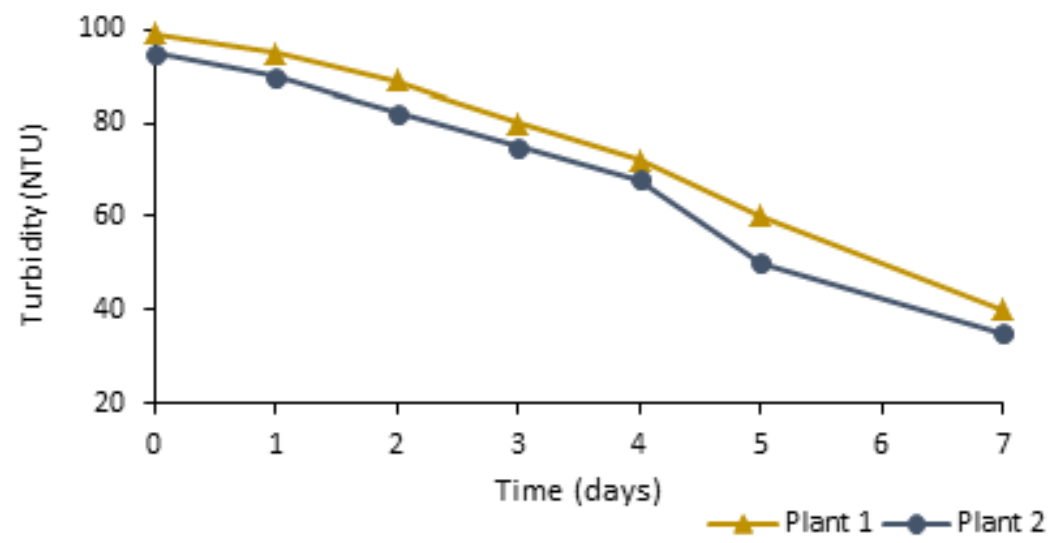

(B)

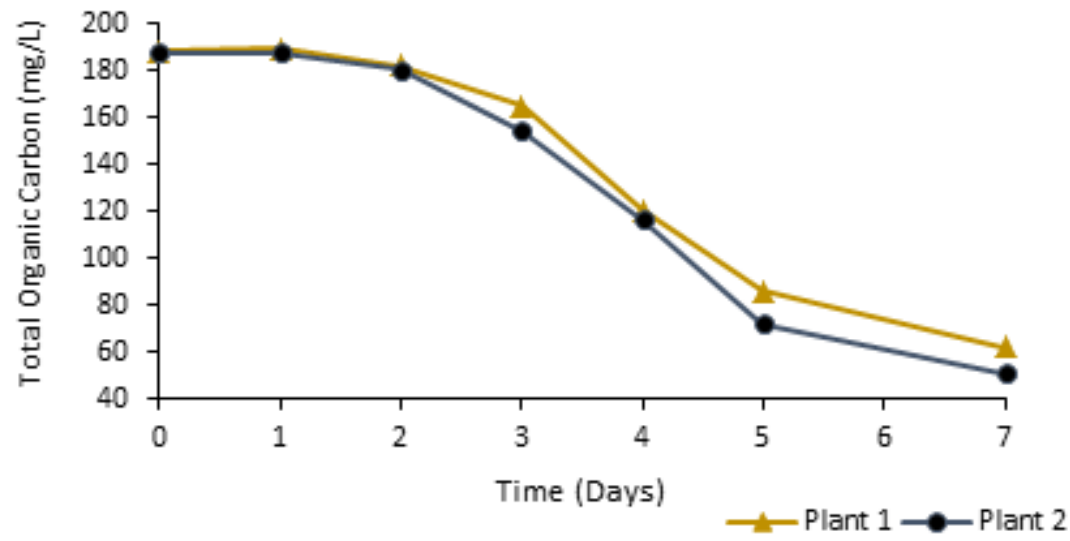

(C)

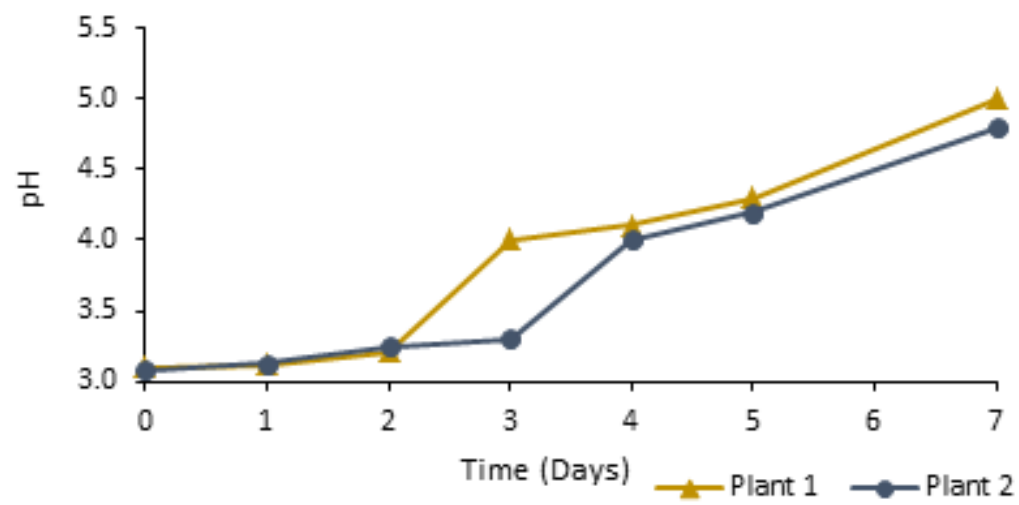

Figure 1. Variations in Physicochemical Properties of the Wastewater during the Study (A) shows variations in mean turbidity while (B) and (C) show variations in mean total organic carbon and $\mathrm{pH}$ levels respectively 


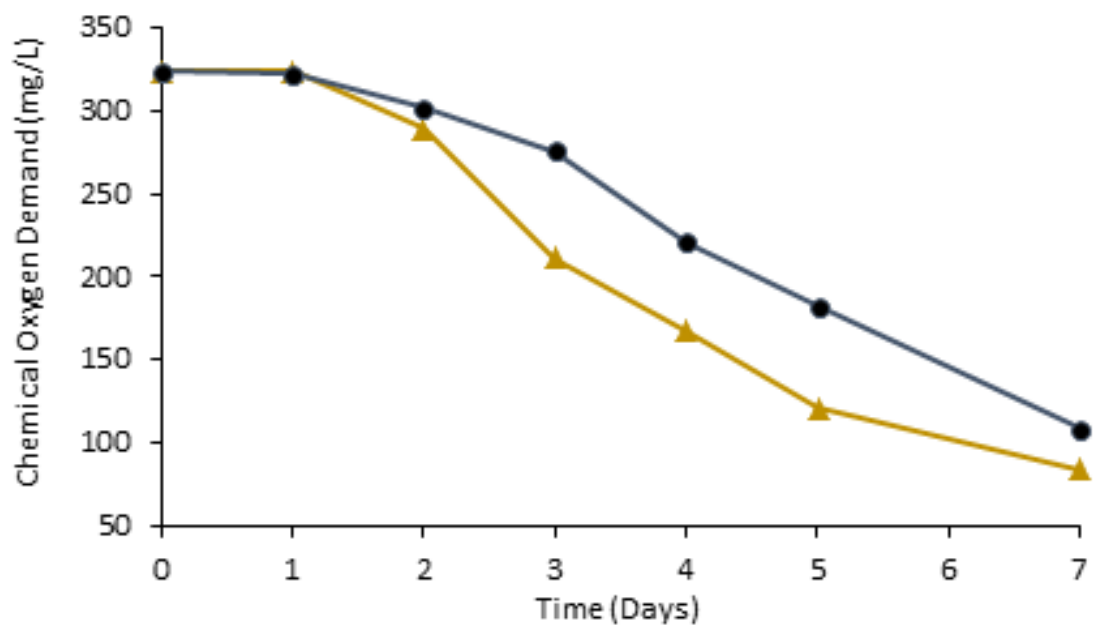

$\longrightarrow$ Plant $1 \longrightarrow$ Plant 2

Figure 2. Variations in Mean Chemical Oxygen Demand of the Wastewater during the Study

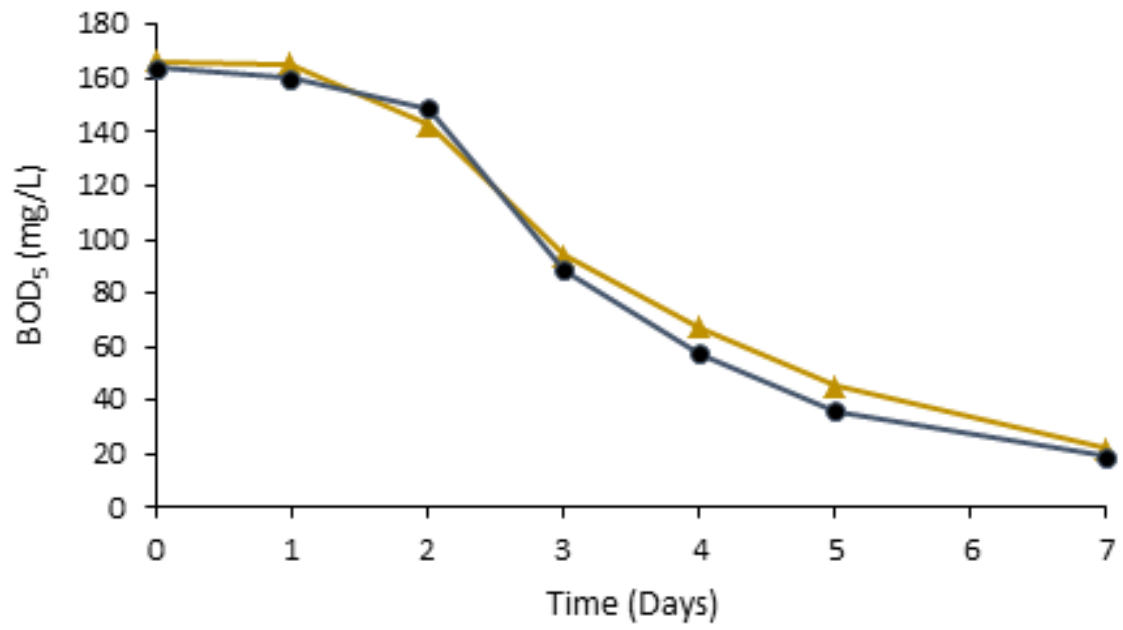

$\longrightarrow$ Plant $1 \longrightarrow$ Plant 2

$\mathrm{BOD}_{5}$ - Biochemical Oxygen Demand

Figure 3. Variations in Five-day Biochemical Oxygen Demand of the Wastewater during the Study

The COD dropped by approximately $74 \%$ in Plant 1 (from $323.69 \mathrm{mg} / \mathrm{L}$ to $83.90 \mathrm{mg} / \mathrm{L}$ ) and $67 \%$ in Plant 2 (from $324.20 \mathrm{mg} / \mathrm{L}$ to $108.4 \mathrm{mg} / \mathrm{L}$ ) as highlighted in Figure 2. With the $\mathrm{BOD}_{5}$, the observed reduction was around $87 \%$ (from $166.02 \mathrm{mg} / \mathrm{L}$ to $22.08 \mathrm{mg} / \mathrm{L}$ ) and $88 \%$ (from $164.31 \mathrm{mg} / \mathrm{L}$ to $19.33 \mathrm{mg} / \mathrm{L}$ ) in Plants 1 and 2 respectively (Figure 3 ).

A strong positive correlation was observed between $\mathrm{BOD}_{5}$ and $\mathrm{COD}$ for both plants studied. The biodegradability indices based on mean values for the 5 -day biochemical oxygen demand and the chemical oxygen demand for the wastewater samples are 0.513 and 0.507 for Plants 1 and 2 respectively (Figure 4).

The bacterial isolates obtained from samples of effluent from both plants at commencement of the study were Escherichia coli, Bacillus sp., Klebsiella sp., Salmonella sp., Streptococcus faecalis, Shigella sp. and Aerobacter aerogenes. Figure 5 shows the variation in mean total viable bacterial and total coliform counts. A 100\% removal of bacteria was observed at the end of the study. The observed percentage reduction in all the water quality parameters studied is shown in Figure 6. 
(A)

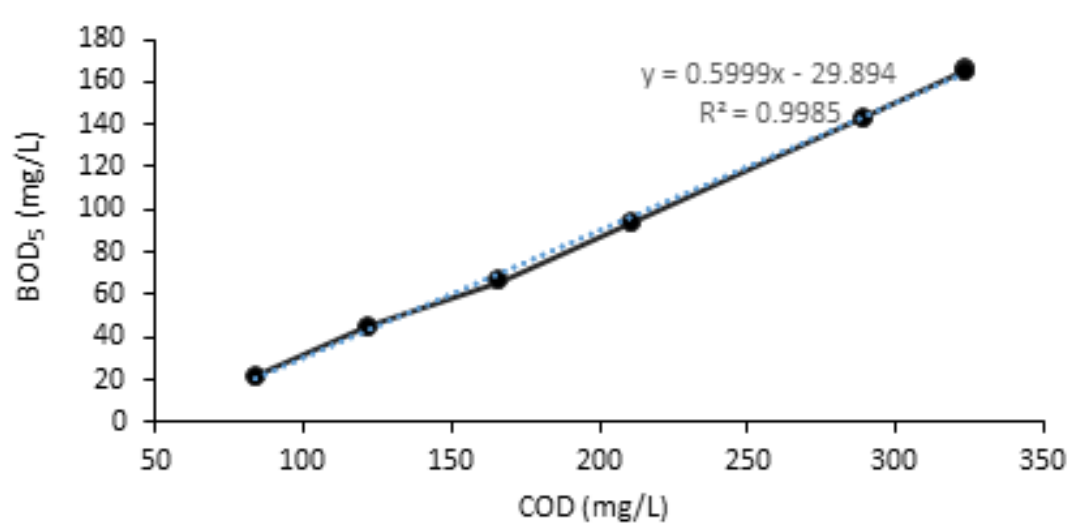

(B)

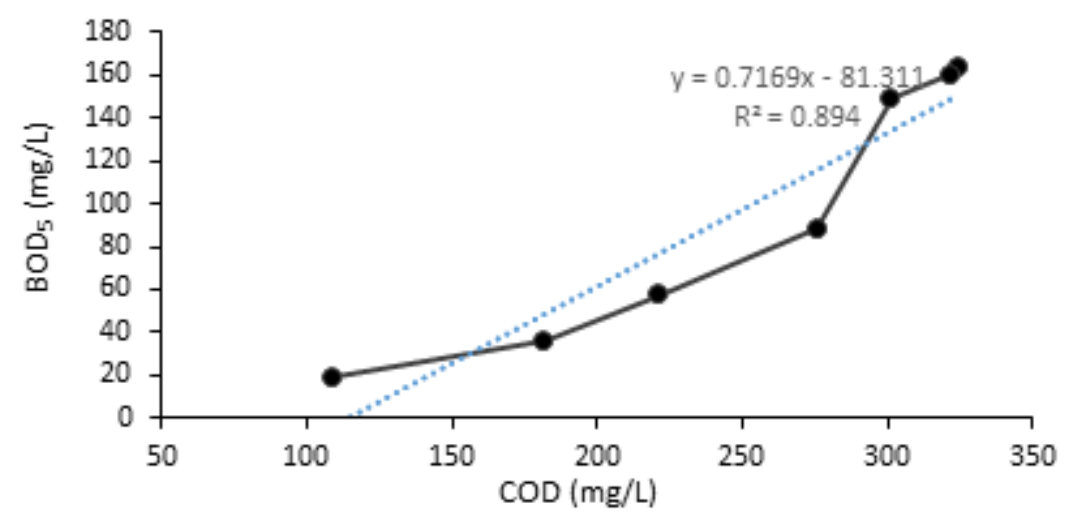

$\mathrm{BOD}_{5}$ - Biochemical Oxygen Demand; COD - Chemical Oxygen Demand

Figure 4. Correlation between $\mathrm{BOD}_{5}$ and $\mathrm{COD}$ for Plant 1 (A) and Plant 2 (B)

(A)

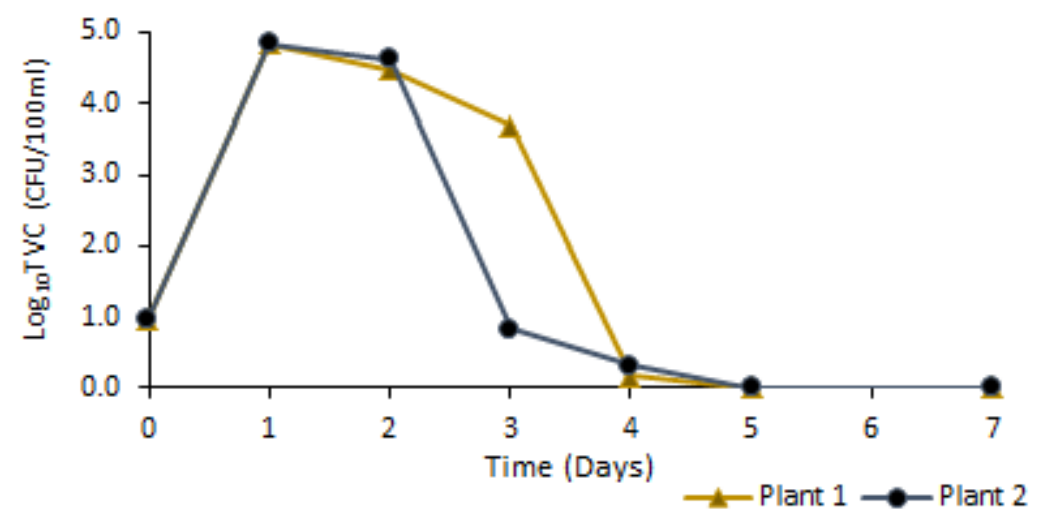

(B)

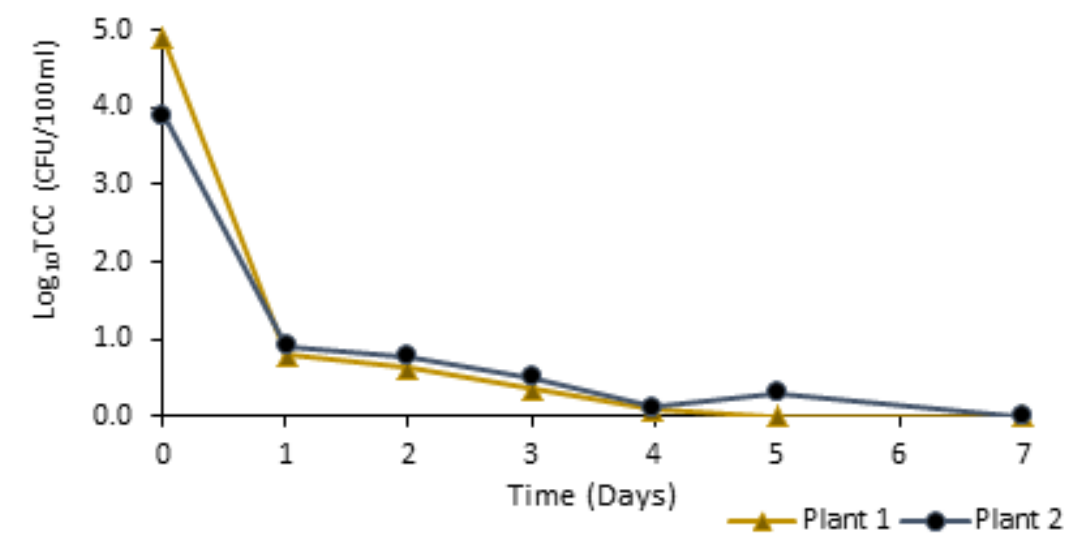

(A) shows variations in mean total viable bacterial counts while (B) shows the variations in mean total coliform counts

Figure 5. Variations in Microbial Abundance of the Wastewater during the Study 


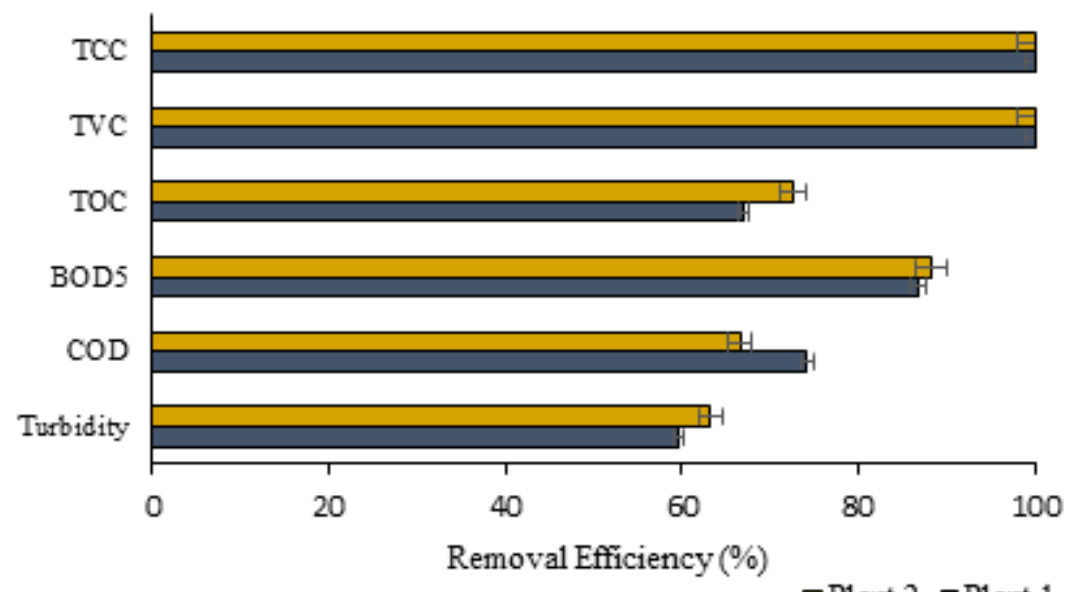

Bars represent the standard error; TCC - Total Coliform count; TVC - Total Viable Bacterial Count; TOC - Total Organic Carbon; BOD $_{5}-$ Five-day Biochemical Oxygen Demand; COD - Chemical Oxygen Demand

Figure 6. Observed Reduction in Water Quality Parameters at the End of the Study

\section{Discussion}

The results obtained highlight the adsorbent capabilities of the MO seed-based coagulant and indicate that it has promising applications in the management of cassava mill effluent. It greatly improved turbidity leaving the water relatively cloudless. The turbidity levels were reduced by about 59\% - 63\% across the two plants studied. Total viable bacteria and coliform bacteria were totally eliminated during the 7 -day study period ( $100 \%$ removal). MO has been described as one of the most scrutinised potential natural coagulants for wastewater treatment [35]. The seed powder is often used and has shown excellent outcomes for effluent from different domestic and industrial sources [36-39]. The essence of biotreatment is to sustainably adjust the biological and physicochemical properties of the wastewater to levels that meet Federal Ministry of Environment (Nigeria) requirements which has been achieved in this study [40].

\section{Physicochemical Properties of Effluent Samples}

Most of the comparable research evaluated reported higher values in the physicochemical parameters than found in this study. Generally MO seed-based coagulant at concentrations of $1 \%-3 \%$ used by different researchers were found to reduce turbidity by about $63 \%-$ $90 \%[35,41,42]$. The results from this study indicated that the set-ups with the MO seed-based coagulant effectively improved the turbidity, total organic carbon and $\mathrm{pH}$ levels in the wastewater samples.

The observed improvement in the turbidity of the samples is in agreement with the reports of Chaudhuri and Khairuldin [43] and Wilson and Andrews [44] who confirmed that MO seed extracts enhanced water clarity and reduced discolouration during wastewater treatment. Madrona et al. [45] suggested that active agents from the MO seed powder acted by binding to the impurities in the water removing them from suspension which then reduced the turbidity. A study by Hendrawati et al. [46] achieved a $97.9 \%-98.6 \%$ reduction in turbidity using an optimum concentration of $10 \% \mathrm{MO}$ seed powder with the initial turbidity level impacting strongly on the determined optimum concentration. This is as opposed to the $2 \%$ concentration used in this study. The turbidity reduction level recorded by [46] is higher than that found in the current study but may be attributed to the higher concentration of MO-based coagulant being about five times more than used in the current study. This conclusion is, however, not supported by Suhartini et al. [47] who concluded that the concentration of the MO seed powder did not impact the efficacy of the coagulation process as there were no significant differences in turbidity outcomes using three different concentrations of MO seed coagulant. They further opined that the efficacy of the process was more dependent on the proteins present. With Trevisan et al. [21], MO seed powder concentrations of about $280 \%$ and $210 \%$ produced the highest reduction in turbidity levels of $89.19 \%$ and $84.44 \%$ respectively. This could be surmised to buttress that MO-based coagulant concentration correlates positively with turbidity levels. An almost total decline in turbidity was observed in the treatment of dairy wastewater using MO seed extracts. The turbidity dropped by approximately $98 \%$ following addition of the coagulant [14]. Akin to the levels obtained in the current study, the use of MO seed-based coagulant alone reduced turbidity in oil refinery wastewater by $63.7 \%$. When used in combination with alum, turbidity reduction increased to $86.14 \%$ [48].

The baseline level of alkalinity or acidity has been highlighted as a key determining factor for the efficiency of coagulation in biological methods of wastewater treatment. Beyond the optimum $\mathrm{pH}$ ranges, successful floc formation is hampered [46]. The baseline $\mathrm{pH}$ for the current study was acidic at approximately 3.0; this $\mathrm{pH}$ was not adjusted and could therefore account for the relatively 
lower percentage decrease in physicochemical parameters when compared to similar studies which record over $90 \%$ reduction. The results from a similar study on cassava mill effluent, in contrast, found that the $\mathrm{pH}$ dropped to acidic levels as the biotreatment using MO-based coagulant proceeded. The drop was linked to the production of organic acids during biodegradation of glucose [21]. The observed changes in $\mathrm{pH}$ may not necessarily be an effect from the coagulant but from the reduction in availability of suspended solids and other contaminants in solution.

While most researchers find that $\mathrm{pH}$ levels are independent of the efficiency of turbidity reduction in biotreatment using MO-based coagulants, others maintain that the two are closely interwoven. Vieira et al. [14] in their study on dairy effluent concluded that $\mathrm{pH}$ levels had a significant effect on the reduction in turbidity while Trevisan et al. [21] suggested that turbidity reduction was greater at more acidic $\mathrm{pH}$ levels. The issue of coagulant dosage may feature here as well. Although Suhartini et al. [47] reported no significant differences in $\mathrm{pH}$ for three varying concentrations of $\mathrm{MO}$ seed powder, Hendrawati et al. [46] found that increases in the quantity of MO seed coagulant applied resulted in corresponding decreases in the $\mathrm{pH}$ of the wastewater samples. A study in Malaysia used MO seed powder to treat industrial wastewater with initial $\mathrm{pH}$ close to neutral. At $2 \%$ concentration, $\mathrm{pH}$ and turbidity declined by about $4 \%$ and $97 \%$ respectively [18]. There was, however, no significant influence in other physicochemical parameters including the $\mathrm{pH}$. Adelodun et al. [49] also found that there was no significant difference in turbidity removal for MO dosage $150 \mathrm{mg} / \mathrm{L}$ and $200 \mathrm{mg} / \mathrm{L}$. The result from a study on municipal effluent treatment using seed of MO depicted that turbidity removal reached a maximum of $94.44 \%$ with $15 \%$ MO biomass, this decreased marginally to $94.42 \%$ when the concentration was raised to $20 \%$. They further highlighted that there was no significant difference for turbidity removal between the two different concentrations.

The high TOC in wastewater is indicative of high environmental pollution potential highlighting the need for treatment before disposal into waterways [50]. Based on the categorisation of Tchobanoglous and Burton [51], the TOC values were initially in the medium class but were brought down to acceptable limits of below $80 \mathrm{mg} / \mathrm{L}$. The observed decrease in the TOC levels in this study by an average of $67.0 \%-72.6 \%$ conflicts with certain reports of increased TOC following the application of MO seed-based coagulant [52]. Okoya et al. [53], however, similar to the current study, recorded a higher value of about $88.9 \%$ TOC reduction during the treatment of wastewater using activated MO seed powder.

\section{Biological Properties of Effluent Samples}

Similar observations to physiochemical characteristics were obtained with the biological characteristics of the effluent. The initial BOD and COD values were far greater than the limits set by Federal Ministry of Environment (Nigeria) [40]. Both the COD and BOD baseline levels in the effluent samples were classed as medium range, however, following biotreatment, the levels were brought down to Low based on the categorisation of Tchobanoglous and Burton [51]. When $\mathrm{BOD}_{5}$ levels are over $100 \mathrm{mg} / \mathrm{L}$, the water is considered to be "very polluted" and therefore, unacceptable for any reasonable use. The $\mathrm{BOD}_{5}$ and $\mathrm{COD}$ levels were successfully lowered to levels within the acceptable disposal limits of $20 \mathrm{mg} / \mathrm{L}$ and $120 \mathrm{mg} / \mathrm{L}$ for $\mathrm{BOD}_{5}$ and COD respectively [40,54]. The observation from this study found that the effectiveness of BOD removal was lower than that in other similar studies $[38,47]$. Adelodun et al. [49] noted maximum removal levels of $68.72 \%$ and $57.61 \%$ for BOD and COD respectively using at $15 \%$ strength MO seed extract.

The possible effectiveness of biological treatment of wastewater is determined by measuring its biodegradability index (BI). BI values ranging from $0.3-$ 1.0 are considered biodegradable and can be effectively treated biologically. When the $\mathrm{BI}$ is less than 0.3 or over 1.0 , the wastewater is considered unsuitable for biological treatment usually due to the presence of potentially toxic chemicals that inhibit the metabolic activities of biodegraders [26]. The BI values define the practicability of treatment methods for effluent. It is expected that BI values for untreated municipal wastewater will characteristically be between 0.4 and 0.8 but may get up to 10 for industrial wastewater suggesting that such wastewater could not be treated using biological means [55]. The BI obtained for both of the cassava plant effluent samples in this study demonstrated high levels of organic matter and was within the range suitable for microbial degradation via natural or enhanced conditions. Tapioca starch wastewater was found to be similarly biodegradable with a BI of 0.3 [47]. Rim-Rukeh [26] managed wastewater from 6 different cassava mills in Nigeria and described mean biodegradability indices of $0.507-0.548$ similar to the values obtained in the current study. They further concluded that there was a strong positive correlation between $\mathrm{BOD}_{5}$ and $\mathrm{COD}$ as found in the present study. The strong positive correlation between $\mathrm{BOD}_{5}$ and COD is buttressed by the report of [31].

In the biotreatment of dairy effluent using MO seed based coagulant, $\mathrm{pH}$ was found to strongly influence $\mathrm{COD}$ levels. A 37\% decline was achieved at $\mathrm{pH}$ 5, increasing to $50 \%$ at $\mathrm{pH}$ of 8 and dropped at $\mathrm{pH}$ level over 8 [14]. Reduction in COD, however, has been reported to be independent of coagulant concentrations unlike BOD. The concentration of the MO seed-based coagulant seemed to play a role in the level of reduction in biological parameters recorded. A study on biotreatment of tapioca starch wastewater using MO seed powder found that BOD 
value decreased with increasing dose of powdered $\mathrm{MO}$ seed. The highest concentration of $15 \%$ coagulant used resulted in the greatest reduction in BOD [47]. In contrast, COD reduction of $50 \%$ was observed with MO seed extract concentrations of both 5\% and 10\% [35]. The removal efficiency for COD has been found to be more closely linked to settling time [39].

The faecal coliforms dominated in this study which differs significantly from other similar studies such as that of Enerijiofi et al. [23] who obtained Pseudomonas, Bacillus, Acetobacter, Rhizopus, Corynebacterium, Lactobacillus, Micrococcus, Aspergillus, Staphylococcus, Penicillum and Saccharomyces from cassava mill effluent. Pseudomonas and Bacillus dominated. The baseline $\mathrm{pH}$ here was much more alkaline at 5.0. The mean initial bacterial counts were much higher than observed in the current study with the value up to $8.531 \mathrm{LogCFU} / 100 \mathrm{ml}$. The dominance of the coliforms amongst the isolates in the current study is likely due to the initial relative acidity of the waste water. Coliform bacteria are known to grow well under fermentation conditions that generate lactic acid and are thus suited to low $\mathrm{pH}$ environments. The addition of the coagulant brings the $\mathrm{pH}$ levels closer to neutral impacting on the growth of the observed microorganism. The antimicrobial capabilities of $M$. oleifera has been extensively reported [56,57]. In a study by Oluduro and Aderiye [58], the growth of $S$. faecalis and $P$. aeruginosa cultured in water was inhibited by the addition of $M$. oleifera seed extracts. This characteristic may play a significant part in the observed removal of both heterotrophic and coliform bacteria. Reduction in BOD was closely linked to reduction in TVBC and TCC. In one study, $M$. oleifera treatment reduced coliform counts by $80 \%$ in wastewater treatment with an $11.7 \%$ decline in BOD observed [48].

\section{Conclusions}

The study confirmed the capacity of the powdered seeds of M. oleifera to improve the physicochemical and microbiological properties of wastewater from cassava processing plants. The treatment with $M$. oleifera improved overall water quality mainly by improving water clarity, reducing the organic matter content and removing bacteria present in the water. At the end of the 7 -day study, turbidity reduced by $59.6 \%-63.2 \%$ while chemical oxygen demand, biochemical oxygen demand and total organic carbon values dropped by $66.6 \%$ $74.1 \%, 86.7 \%-88.2 \%$ and $67.0 \%-72.6 \%$ respectively. The heterotrophic and coliform bacteria were completely removed. It can be concluded that Moringa oleifera seed powder can successfully serve as the primary treatment for cassava processing mill effluent.

\section{REFERENCES}

[1] Verma R.K., Kumar R., Sethi M. Use of distinct parts of Moringa oleifera in domestic wastewater treatment (An analogous study). $8^{\text {th }}$ International Conference on Reliability, Infocom Technologies and Optimisation (Trends and future Directions), Noida, India, 2020, pp463 - 467.

[2] UN-Water. UN-Water Annual Report 2010. UN-Water, Geneva, Switzerland, 2010.

[3] Tiseo I. Global key figures on wastewater generation 2020. 2020

https://statistica.com/statistics/1124488/key-facts-wastewat er-generation-globally/ (accessed $20^{\text {th }}$ February, 2021).

[4] Majumder D., Maity J.P., Tseng M.J., Nimje V.R., Chen H.R., Chen C.C., Chang Y.F., Yang T.C., Chen, C.Y. Electricity Generation and Wastewater Treatment of Oil Refinery in Microbial Fuel Cells Using Pseudomonas putida. Int. J. Mol. Sci., 15(9), 16772 - 16786, 2014.

[5] Osadebe AU, Okounim B. Multidrug-resistant bacteria in the wastewater of the hospitals in Port Harcourt metropolis: Implications for environmental health. Journal of Advances in Environmental Health Research, 8(1): 49 - 58, 2020.

[6] Arafat M.G. and Mohamed S.O. Preliminary Study on Efficacy of Leaves, Seeds and Bark Extracts of Moringa oleifera in Reducing Bacterial load in Water. International Journal of Advanced Research, 1, 124-130, 2013.

[7] Horne J. Economic Approaches to Water Management in Australia. International Journal of Water Resources Development, 29, 526-543, 2013.

[8] Johnstone D.W.M. Regulation and Reality: Some Reflections on 50 Years of International Experience in Water and Wastewater. International Journal of Water Resources Development, 30, 345-354, 2013.

[9] Li H, Wu S, Du C, Zhong Y, Yang C. Preparation, Performances, and Mechanisms of Microbial Flocculants for Wastewater Treatment. Int. J. Environ. Res. Public Health 2020, 17, 1360, 2020.

[10] WHO, World Health Organisation. Guideline for Drinking Water Quality (Electronic Resources): Incorporating First Addendum, vol. 1, 3rd Edition. WHO, Geneva, Switzerland, 2006.

[11] Gautam S, Saini, G. Use of natural coagulants for industrial wastewater treatment. Global Journal of Environmental Science and Management 6(4): 553 - 578, 2020.

[12] Nath, A., Mishra A., Pande, P.P. A review of natural polymeric coagulants in wastewater treatment. Materials Today: Proceedings, s2214785320323324, 2020. doi.org/10.1016/j.matpr.2020.03.551

[13] Muthuraman G., Sasikala S. Turbidity removal from drinking water using natural coagulant. J. Ind. Eng. Chem. 20(4): 1727 - 1731, 2014.

[14] Vieira A., Vieira M., Marquetotti A., Vieira S., Vieira M.F., Silva G.F. Use of Moringa oleifera seed as a natural adsorbent for wastewater treatment. Water Air Soil Pollution, 206: 273-281, 2010. 
[15] Gidde M.R., Bhalerao A.R., Malusare C.N. Comparative Study of Different Forms of Moringa oleifera extracts for turbidity Removal. International Journal of Engineering Research and Development, 2, 14 - 21, 2012.

[16] Egbuikwem P.N., Sangodoyin A.Y. Coagulation Efficacy of Moringa oleifera Seed Extract Compared to Alum for Removal of Turbidity and E. coli in Three Different Water Sources. European International Journal of Science and Technology, 2, 13-20, 2013.

[17] Ibiene A.A., Osadebe A.U., Ekwuribe N.C., Okerentugba P.O. Moringa oleifera Seed Powder for Improvement of the Microbiological and Physicochemical Quality of Sullage and River Water. PSM Biological Research, 6(2): 34-45, 2021.

[18] Eman N.A., Tan C.S., Makky E.A. Impact of Moringa oleifera Cake Residue Application on Waste Water Treatment: A Case Study. Journal of Water Resource and Protection, 6, 677 - 687, 2014.

[19] Bongiovani M.C., Pereira Camacho F., Cardoso Valverde K., Rhuna Tonial Dos Santos T., Nishi L., Bergamasco R. Evaluation of trihalomethanes formation using combined process coagulation/floculation/membranes in water treatment, Chemical Engineering Transactions, 43, 2323 2328, 2015.

[20] Ahmed, S., Aktar, S., Zaman, S., Jahan, R.A., Bari, M.L. Use of natural bio-sorbent in removing dye, heavy metal and antibiotic-resistant bacteria from industrial wastewater. Appl. Water Sci., 10:107, 2020

[21] Trevisan A.P., Lied E., Fronza F.L., Devens K., Gomes S. Cassava Wastewater Treatment by Coagulation/flocculation Using Moringa Oleifera Seeds, Chemical Engineering Transactions, 74, 367-372, 2019.

[22] Magalhães ERB, de Menezes NNF, Silva FL, Garrido JWA, Sousa MADB, dos Santos ES. Effect of oil extraction on the composition, structure and coagulant effect of Moringa oleifera seeds. Journal of Cleaner Production, 279, 123902, 2021.

[23] Enerijiofi K.E, Ekhaise F.O, Ekomabasi I.E. Biodegradation Potentials of Cassava Mill effluent (CME) by indigenous microorganisms. Journal of Applied Science and Environmental Management, 21 (6), 1029 - 1034, 2017.

[24] Padmaja G. Cyanide detoxification in cassava for food and feed uses. Critical Reviews in Food Science and Nutrition 7(5): 299 - 339, 2007.

[25] Eziegbo O.R., Ike-Amadi C.A., Okeke U.P., Ekiko M.U. The effect of cassava mill effluent on soil microorganisms in Aba, Nigeria. Int J Curr Res Biosci Plant Biol. 1(4): 21 - 26, 2014.

[26] Rim-Rukeh A. Biodegradability assessment of cassava processing mill wastewater effluent. American-Eurasian Journal of Agriculture and Environmental Science 16(5), 946-951, 2016.

[27] Jahn S.A.A. Using Moringa seeds as coagulants in developing countries. Journal AWWA, 80(6): 43 - 50, 1988.

[28] USEPA, United States Environmental Protection Agency. Water: Monitoring and Assessment, 2012. Retrieved from https://archive.epa.gov/water/archive/web/html/index-19.ht $\mathrm{ml}$ (Accessed 20-02-2020).
[29] ASTM. Standard Test Methods for Chemical Oxygen Demand (Dichromate Oxygen Demand) of Water. West Conshohocken, PA: ASTM International, 2012.

[30] APHA, American Public Health Association. Standard Methods for the Examination of Water and Waste Water $21^{\text {st }}$ Edition American Public Health Association, Washington, D.C., 2005.

[31] Abdalla K.Z., Hammam G. Correlation between Biochemical Oxygen Demand and Chemical Oxygen Demand for Various Wastewater Treatment Plants in Egypt to Obtain the Biodegradability Indices. International Journal of Sciences: Basic and Applied Research, 13, 1, 42-48, 2014

[32] APHA and AWWA, American Public Health Association, American Water Works Association (2012). Standard methods for the examination of water and wastewater. Washington, DC:

[33] Cheesebrough M. District Laboratory Practice in Tropical Countries. Part II, London, Cambridge University Press, 2006. pp58- 100 .

[34] Holt G.T., Krieg R.N., Sneath P.H.A., Staley T.J., Williams T.S. Bergey's Manual of Determinative Bacteriology. $9^{\text {th }} \mathrm{Ed}$. Williams and Wilkins, Baltimore, USA, 1994.

[35] Bhuptawat H, Folkard GK, Chaudhari S. Innovative physicochemical treatment of wastewater incorporating Moringa oleifera seed coagulant. Journal of Hazardous Materials, 142, 1-2, 477-82, 2007.

[36] Parmar K., Dabhi Y., Patel R., Prajapati, S. Effectiveness of Moringa oleifera as natural coagulant aid for waste water treatment of dairy industry. Asian J. Environ. Sci., 7,2, 167 $171,2012$.

[37] Sulaiman M., Umar D.M., Aliyu B., Manan F.A. Moringa oleifera seed as alternative natural coagulant for potential application in water treatment: A review. J. Adv. Res. Mat. Sci. 56, $11-21,2017$.

[38] Ashmawy MA, Moussa MS, Ghoneim AK, Tammam A. Enhancing the efficiency of primary sedimentation in wastewater treatment plants with the application of Moringa oliefera seeds and quicklime. J Am Sci 8, 494-502, 2012.

[39] Dotto J., Fagundes-Klen M.R., Veit M.T., Palácio S.M., Bergamasco R. Performance of different coagulants in the coagulation/flocculation process of textile wastewater. $J$. Clean. Prod., 208, 656-665, 2019.

[40] FMoE, Federal Ministry of Environment (Nigeria). National Guidelines and Standards for the Water Quality in Nigeria. Government Publishers, Lagos, 1995.

[41] Bina B, Shasavani A, Asghare G, Hasanzade A. Comparison of water turbidity removal efficiencies of Moringa oleifera seed extract and poly-aluminum chloride. Water Waste Journal 18, 1, 24 - 33, 2007. [Translated from persian].

[42] Mehdinejad MH, Bina B, Nikaeen M, Movahedian Attar H. Effectiveness of Moringa oleifera Coagulant Protein and Chitosan as natural coagulant aids in removal of colloidal particles and bacteria from turbid waters. Journal of Gorgan University of Medical Sciences, 11(3): 60 - 69, 2009. [Translated from persian]. 
[43] Chaudhuri M., Khairuldin P.S.A.B. Coagulation-clarification of turbid coloured water by natural coagulant (Moringa oleifera) seed extract. Nat Environ Pollut Technol 8:137-139, 2009.

[44] Wilson S.A., Andrews S.A. Impact of a natural coagulant pre-treatment for colour removal on solar water disinfection (SODIS). JWaSHDev 01:57-67, 2011.

[45] Madrona G.S, Branco I.G., Seolin V.J., Bdaa F., Fagundes-Klen M.R.., Bergamasco R. Evaluation of extracts of Moringa oleifera Lam seeds obtained with $\mathrm{NaCl}$ and their effects on water treatment. Acta Sci-Technol 34, 289-293, 2012.

[46] Hendrawati H., Yuliastri I.R., Nurhasni N., Rohaeti E., Effendi H., Darusman L.K. The use of Moringa Oleifera Seed Powder as Coagulant to Improve the Quality of Wastewater and Ground Water. IOP Conference Series: Earth and Environmental Science 31(1): 012033, 2016. doi:10.1088/1755-1315/31/1/012033

[47] Suhartini S., Hidayat N., Rosaliana E. Influence of powdered Moringa oleifera seeds and natural filter media on the characteristics of tapioca starch wastewater. International Journal of Recycling of Organic Waste in Agriculture, 2:12, 2013.

[48] Dehghani M., Alizadeh M.H. The effects of the natural coagulant Moringa oleifera and alum in wastewater treatment at the Bandar Abbas Oil Refinery. Environmental Health Engineering and Management Journal, 3(4), 225230, 2016.

[49] Adelodun B., Ogunshina M.S., Ajibade F.O., Abdulkadir T.S., Bakare H.O., Choi K.S. Kinetic and Prediction Modelling Studies of Organic Pollutants Removal from Municipal Wastewater using Moringa oleifera Biomass as a Coagulant. Water, 12, 2052, 2020.
[50] Penn M.R., Pauer J.J., Mihelcic J.R. Biochemical Oxygen Demand In: Sabljic A (ed.) Environmental and Ecological Chemistry, vol 2. UNESCO EOLSS, Isle of Man, UK, 2009.

[51] Tchobanoglous G., Burton F.L. Wastewater Engineering: Treatment and Reuse, 4th Ed., McGraw-Hill York, USA, 2003.

[52] Awad M., Wang H., Fengting L. Weakness of Moringa oleifera use in water treatment. International Journal of Current Research, 5, 5, 1165 - 1167, 2013.

[53] Okoya OO., Akinyele A.B., Ochor N.O. Efficacy of Moringa oleifera seed husk as adsorptive agent for trihalomethanes from a water treatment plant in southwestern Nigeria. Journal of Chemistry 2020, Article ID 3450954, 2020.

[54] DPR, Department of Petroleum Resources (Nigeria). Environmental Guidelines and Standards for the Petroleum Industry in Nigeria. Government Press, Lagos, 2002.

[55] Achoka J.D. The efficiency of oxidation ponds at the Kraftpulp and Paper Mill at Webuye in Kenya. Water Resources, 36, 1203 - 1212, 2002.

[56] Lürling M., Beekman W. Anti-cyanobacterial Activity of Moringa oleifera Seeds. Journal of Applied Phycology, 22, 4, $503-510,2010$.

[57] Bukar A., Uba A., Oyeyi T.I. Antimicrobial profile of Moringa oleifera Lam. extracts against some food-borne microorganisms. Bayero Journal of Pure and Applied Sciences, 3(1), 43 - 48, 2010.

[58] Oluduro A.O., Aderiye B.I. Efficacy of Moringa oleifera seed extract on the Microflora of Surface and Underground Water. Journal of Plant Sciences 2, 4, 453 - 458, 2007. 